Sir,-I have read with much interest the references made by Sir Henry H. Howorth to Glacial action in Iceland, in the course of his article in your July Number, pp. 302-309.

Having travelled through the country twice (1890 and 1891), mainly in quest of the summit of its highest peak, which was reached during the latter journey, I have had good and numerous opportunities of observing the peculiarities of its mountain structure.

On the whole, there can be no doubt as to the general result being decidedly in favour of Sir Henry's view. The instances he refers to are, however, of varying value. The gnarled points of such ridges as those of Almannagja can hardly be regarded as offering conclusive proof, since these are lava splits, and of too recent (geological) date to found an extensive inference upon; nor will Mr. Baring Gould's remarks as to the aqueous origin of apparently glacial striations apply to the marks which are plentiful at certain intermediate levels upon the mountains. These may be found, especially among the valleys leading to the Eastern fjörds, in positions too high above flood courses to permit of such an explanation. Nor will Mr. Watts' remarks as to the extension of the southern glaciers command universal acceptance now. On the other hand, however, it is of the utmost importance to notice that among the hard basalt masses of the east and south-east, the lower ridges up to the height of about 1000 to 1500 feet are often rounded, and striations are not uncommon; but above that height, at elevations which increase as one travels inland, these rounded hill-tops disappear, and sharp pinnacles form the rule. So sharp are these pinnacles that it takes a stranger some time to realize that they are not columns built upon the mountain summits. In point of fact each is the nucleus of the uppermost layer of the Trap beds, from which the rest of that bed has split away. Here is a far older and safer guide, telling of a time when many of these valleys, up to a certain level, had their glaciers; which, however, never formed part of an ice-cap to the island. So marked is the distinction between these peaks, rounded and pinnacled, that the conviction I have stated fairly forces itself upon one.

Further west along the south coast evidence of another kind is forthcoming from the volcanic masses which there replace the basalt of the south-east and north-west. So soft are many of the ridges that, on the hypothesis of a huge grinding ice-cap, they ought to have disappeared altogether. Yet there they remain, loose, shalylaminated ridges, between which, in the valleys, lie enormous snowfields with drainage glaciers coming down to sea-level now and overtopping lower hills, just as the most easterly ones used to do. On every hand signs abound, both of advance and of retreat, on the part of glaciers accommodating themselves to the inequalities of their beds, but none whatever of ice above a definite ascending level, nor of excavations beneath that level.

It is true large quantities of mud are brought down by such 
rivers as the Jökulsá, but it would be strange if glaciers, twelve miles wide, did not produce such results by mere surface erosion. The wonder is they bring so little. But of this the probable explanation is the gentle fall-which I have ascertained to be about 100 feet per mile of progress in the case of the Breithamerkr-and the few uncovered ridges or peaks from which material may fall upon the ice.

Fredk. W. W. Howell.

10, Handsworth Wood Road, Birmingham, $J x l y 14 t h, 1893$.

OBITUARY.

\section{JAMES WILLIAM DAVIS, F.L.S., F.G.S., F.S.A.}

Bors APrit 15, 1846. Died July 21, 1893.

IT is with deep regret that we announce the death of Mr. James Wm. Davis, of Chevinedge, Halifax, at the comparatively early age of 47. A Yorkshireman of fine physique and robust constitution, endowed with apparently unlimited energy, the sad news of his loss has come as an unexpected shock to his large circle of friends both at home and abroad. His more intimate acquaintances were aware that a slight injury to a blood-vessel in the brain caused his retirement from active life for a few weeks last autumn; and they further learned with sorrow that a recurrence of the same malady last March necessitated a still longer period of rest at the littlo village of Grassington, in North Yorkshire. His letters, however, were cheerful, only marred by some feebleness in the handwriting, and when he returned to his seaside residence at Bridlington about the end of June, there were hopeful signs of speedy recovery. Mr. Davis' eagerness to fulfil his municipal duties at Halifax, however, led to an unwise visit to the town of which he was for the third time Mayor. The fatigue and unwonted excitement produced almost complete paralysis, and his wife, family, and friends had soon to mourn over his decease, which took place early in the morning of July 21st.

Descended from a Gloucestershire family, Mr. Davis was born at Leeds on April 15th, 1846. He was educated at the local Grammar School, and at an early age entered the cloth-dyeing business of his father. He and a brother soon became partners in the firm, which transferred its business to Greetland, near Halifax, and for the remainder of his life Mr. Davis took the leading share of its management. In 1876 he built his fine residence, Chevinedge, on a wooded ridge of Carboniferous Sandstone overlooking Greetland, and there are few geologists of note in Britain who have not enjoyed the hospitality of that modern English home.

Though deeply alsorbed in his own business and in certain collateral undertakings - though taking a prominent position in every educational, municipal, and political movement in his own town and district, and elected Mayor of Halifax no less than three years in succession-Mr. Davis found time not only to become a well-known and valued patron of Art and Science, but also to rise 